\title{
BAGAIMANA MERANCANG SISTEM MANAJEMEN KINERJA?
}

\author{
Wienda P. Rahardja \\ Margaretha Banowati Talim \\ Albert Kurniawan Purnomo \\ Universitas Katolik Parahyangan, Bandung \\ Email: wendarahardja@gmail.com; bano@unpar.ac.id; kurniawanalbert@yahoo.com \\ Submitted: Jan 24, 2018; Reviewed: Jan 24, 2018; Accepted: Apr 04, 2018
}

\begin{abstract}
This research proposes a performance management model based on existing theories, the concept to be developed using qualitative methods. The purpose of this paper was to find the model of performance management system with benchmarking and balanced scorecard approach. The challenge of this research is the implementation of this design model is still a few companies in Indonesia who can apply it. The final implication of this research is to provide a complex model of performance management system for companies that need and will implement it, as well as relevant for practitioners and academics, as it clarifies existing knowledge and provides a platform for further research.
\end{abstract}

Keywords: Performance Management, Performance Measurement, Benchmarking, Balanced Scorecard, KPI

\section{PENDAHULUAN}

Perusahaan yang ingin berkembang seharusnya memiliki sistem performance management yang baik agar kepuasan kerja karyawan bisa tercapai. Performance Management merupakan proses berkesinambungan untuk mengidentifikasi, mengukur, dan mengembangkan kinerja anggota organisasi serta menyelaraskan kinerja anggota organisasi tersebut dengan tujuan strategis organisasi. Performance Management dapat berupa proses di mana penggerak organisasi berjalan melalui definisi misi, strategi dan tujuan organisasi yang sistematis. Performance Management dengan penerapannya yang tepat dapat meningkatkan kinerja karyawan. Performance Management (PM) dapat didefinisikan sebagai proses yang menggabungkan tujuan, kinerja dan pengembangan dalam sebuah sistem, dimana tujuan utamanya adalah untuk memastikan bahwa kinerja karyawan mendukung tujuan strategis organisasi (Aguinis, 2013; Waal, 2011; Jaksic, 2013).

\section{RUMUSAN MASALAH}

Dari latar belakang, maka peneliti merumuskan beberapa masalah sebagai berikut:

Bagaimana Merancang Sistem Manajemen Kinerja?

\section{TUJUAN PENELITIAN}

Penelitian ini bertujuan untuk menjawab rumusan masalah yang telah dipaparkan, yaitu untuk Merancang Sistem Manajemen Kinerja

\section{TINJAUAN PUSTAKA}

Performance Measurement

Perusahaan harus mengupayakan cara untuk memaksimalkan performance managemenet (PM) yaitu dengan cara mengukur kinerja perusahaan terlebih dahulu (performance measurement) (Ljungholm, 2015). Performance measurement merupakan suatu proses penilaian tentang kemajuan pekerjaan terhadap tujuan dan sasaran dalam pengelolaan sumber daya manusia untuk menghasilkan barang ataupun jasa. Aktivitas performance measurement (pengukuran kinerja) harus disesuaikan dengan tujuan organisasi. Beberapa aspek mendasar dan 
utama dalam mengukur kinerja, yaitu sebagai berikut:

1. Menetapkan tujuan, sasaran dan strategi organisasi, dengan menetapkan secara umum apa yang diinginkan oleh organisasi sesuai dengan tujuan, visi dan misinya.

2. Merumuskan indikator kinerja dan ukuran kinerja. Indikator kinerja mengacu pada pengukuran kinerja secara langsung yang berbentuk Key Performance Indicator (KPI).

3. Mengukur tingkat capaian dan sasaran organisasi, menganalisis hasil pengukuran kinerja dapat diimplementasikan dengan membandingkan tingkat capaian tujuan dan sasaran organisasi tersebut atau bisa disebut dengan (benchmarking).

4. Mengevaluasi kinerja dengan menilai kemajuan organisasi dan pengambilan keputusan yang berkualitas, memberikan gambaran atau hasil kepada organisasi seberapa besar tingkat keberhasilan tersebut dan mengevaluasi langkah apa yang diambil organisasi selanjutnya (Moeheriono, 2009).

\section{Pengertian Key Performance Indicators}

KPI (key performance indicators) pada dasarnya adalah bagian dari Performance Indicators atau indikator kinerja organisasi. Keunggulan KPI dibandingkan dengan indikator-indikator kinerja lainnya, adalah bahwa KPI merupakan indikator kunci yang benar-benar mampu mempresentasikan kinerja organisasi secara keseluruhan. Jumlah indikator kinerja yang dipilih sebagai KPI ini biasanya tidak banyak, namun demikian hasil pengukuran melalui indikator tersebut dapat digunakan untuk memberikan gambaran yang jelas tentang faktor persaingan organisasi, menilai tingkat keberhasilan organisasi dalam mencapai tujuan dan sasaran yang telah ditetapkan, serta memfasilitasi proses pengukuran kinerja secara keseluruhan (Carlucci, 2010; Asropi 2007).

\section{Pengertian Benchmarking}

Benchmarking adalah strategi yang berpotensi menguntungkan yang memungkinkan perusahaan membandingkan produk, layanan dan proses kerja mereka dengan organisasi lain untuk meningkatkan kualitas. Benchmarking bisa bersifat internal, kompetitif atau generik.

a.Benchmarking internal adalah perbandingan antara aktivitas dan proses internal organisasi. Ini adalah tahap analisis yang berguna dalam prosedur kualitas yang mengidentifikasi standar operasi yang ada di dalam perusahaan.
b.Benchmarking kompetitif memungkinkan perusahaan untuk membandingkan operasi dengan para pesaing pada industry yang terkait dengan mengidentifikasi kekuatan dan kelemahan perusahaan pesaing.

c. Benchmarking generik adalah untuk melihat lebih luas, membandingkan proses bisnis atau fungsi bisnis dalam rangka untuk mengidentifikasi praktek perusahaan terbaik pada industri yang tidak berkaitan. Sebagai contoh, perusahaan dari semua jenis mempertimbangkan cara di mana beberapa perusahaan Jepang dapat beroperasi secara fleksibel dan kohesif (Ingram, 1996; Ljungholm, 2015).

\section{Pengertian Balanced Scorecard}

Perusahaan menggunakan aspek-aspek pengukuran seperti KPI, serta benchmarking seperti yang telah dijelaskan sebelumnya, tentu dirasa belum cukup, karena aspek-aspek tersebut hanya melihat dari satu perspektif saja, yaitu perspektif non keuangan, sedangkan saat ini manajemen dituntut untuk meningkatkan kemampuan perusahaannya dalam melipatgandakan kinerja keuangan secara berkesinambungan. Maka dari itu metode balanced scorecard digunakan untuk menjawab permasalahan tersebut (Moeheriono, 2009)

Balanced Scorecard adalah sistem manajemen yang menerjemahkan visi dan strategi organisasi ke dalam tindakan. Di dalam balanced scorecard tindakannya adalah berupa pengukuran yang strategis (Jabeen, 2017; Ljungholm, 2015; Maley, 2014; Tabatabai, 2014; Waal, 2007). Dengan penggunaan metode balanced scorecard (BSC) akan menjelaskan secara rinci kinerja dan tujuan organisasi. Balanced scorecard itu akan membentuk suatu key performance indicators (KPI) yang efektif karena telah disesuaikan terlebih dahulu dengan kondisi perusahaan (Ljungholm, 2015). Penggunaan indikator-indikator pada KPI harus diidentifikasi terlebih dahulu melalui praktik benchmarking baik itu secara internal ataupun eksternal agar indikator-indikator pada KPI tersebut lebih obyektif untuk mengevaluasi pencapaian tujuan strategis sebuah organisasi. Praktik benchmarking akan mengurangi tingkat kegagalan penerapan Balanced Scorecard yang disebabkan oleh indikator-indikator KPI yang tidak jelas atau pengukuran tersebut tidak mendukung tujuan organisasi (Jabeen, 2017; Waal, 2007) 
Pada Gambar 1 kita bisa melihat bahwa penggunaan balanced scorecardmempunyai empat perspektif yang berfungsi untuk mengevaluasi kinerja perusahaan, beberapa jenis perpsektif tersebut antara lain, yaitu: financial perspective, customer perspective, internal business process perspective, dan learning and growth perspective (Kaplan, 2010).

\section{Gambar 1. Structure for the Balanced Scorecard (BSC)}

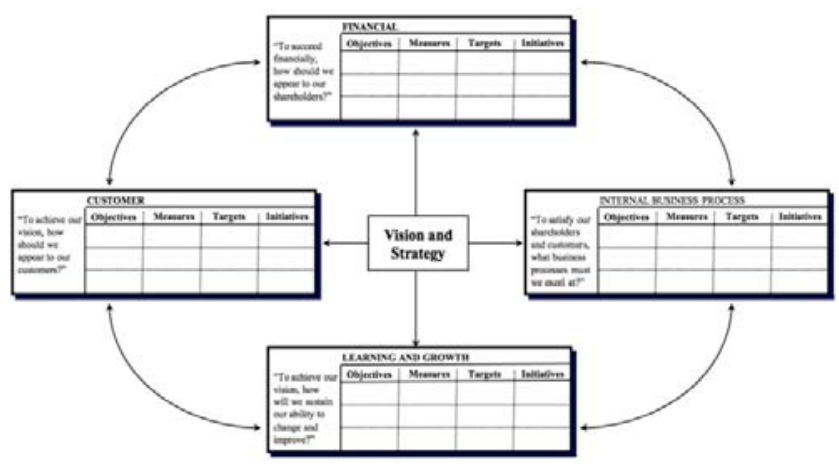

Sumber: Kaplan, 2010

Untuk lebih detailnya kita bisa melihat pada tabel 1 bahwa keempat perspektif tersebut masing-masing dapat diukur dengan penggunaan beberapa macam ukuran ataupun pendekatan yang berbeda.

Tabel 1. Perspektif Pendekatan Balanced Scorecard

\begin{tabular}{|c|c|}
\hline Perspektif & Ukuran Kinerja Eksekutif yang Berimbang \\
\hline \multirow{4}{*}{$\begin{array}{l}\text { Keuangan } \\
\text { (Finance) }\end{array}$} & a. Economic value added (EVA) \\
\hline & b. Pertumbuhan pendapatan (revenue growth) \\
\hline & c. Pemanfaatan aktiva yang diukur dengan asset turnover \\
\hline & d. Berkurangnya biaya secara signifikan yang diukur dengan cost effectiveness \\
\hline \multirow{4}{*}{$\begin{array}{l}\text { Konsumen } \\
\text { (Customer) }\end{array}$} & a. Jumlah customer baru \\
\hline & b. Jumlah customer yang menjadi non customer \\
\hline & c. Kecepatan waktu layanan customer \\
\hline & d. Tingkat kepuasan customer \\
\hline \multirow{3}{*}{$\begin{array}{c}\text { Proses } \\
\text { (Process) }\end{array}$} & a. Ketepatan waktu produksi (cycle time) \\
\hline & b. Ketepatan pesanan (on-time delivery) \\
\hline & c. Perputaran keefektifan (cycle effectiveness) \\
\hline \multirow{6}{*}{$\begin{array}{c}\text { Pembelajaran } \\
\text { dan } \\
\text { Pertumbuhan } \\
\text { (Learning and } \\
\text { Growth) }\end{array}$} & a. Rasio ketersediaan informasi \\
\hline & b. Tingkat kepuasan karyawan \\
\hline & c. Tingkat pemberdayaan karyawan \\
\hline & d. Tingkat produktifitas karyawan \\
\hline & e. Presentase saran yang diimplementasikan \\
\hline & f. Tingkat pencapaian kriteria pendukung keberhasilan tim \\
\hline
\end{tabular}

Sumber: (Moeheriono, 2009)

Dengan penggunaan metode balanced scorecard tersebut maka kita akan bisa mengidentifikasi indikator-indikator baru yang nantinya akan menjadi pedoman penilaian bagi eksekutif untuk menilai bawahannya. Indikatorindikator tersebut jika dirangkai akan menjadi kunci atau alat untuk mengukur tingkat keberhasilan seseorang dalam menjalankan dan melaksanakan tugasnya. Serangkaian indikator kinerja tersebut lebih dikenal dengan nama Key Performance Indicators (Moeheriono, 2009)

Sebuah KPI yang baru berguna sebagai pedoman untuk menyusun penilaian kinerja yang nantinya akan menjadi fondasi dari keseluruhan proses performance management di dalam organisasi (Qureshi, 2013).

\section{Pengertian Performance Management}

Performance Management (Manajemen Kinerja) juga didefinisikan sebagai proses yang menggabungkan tujuan, kinerja dan pengembangan dalam sistem yang unik, dimana tujuan utamanya adalah memastikan bahwa kinerja karyawan mendukung tujuan strategis organisasi. Manajemen kinerja mencakup skema, pendekatan dan prosedur yang direncanakan untuk mengarahkan perhatian manajer dan pekerja terhadap peningkatan operasi perusahaan. Praktik manajemen kinerja memunculkan potensi keberhasilan pelaksanaan kegiatan di masa depan untuk mencapai tujuan organisasi dan individu. Manajemen kinerja mengacu pada proses berkelanjutan yang mencakup penetapan dan perencanaan tujuanserta sasaran, pembinaan dan pengembangan staf, penilaian kinerja, feedback, evaluasi kinerja secara formal serta menghubungkan kinerja dengan penghargaan, sehingga tujuan dari proses yang berlangsung tersebutdapat meningkatkan kinerja karyawan. Peningkatan kerja karyawan mencakup kepuasan kerja dan komitmen terhadap organisasi serta kinerja organisasi itu sendiri (Smither 2009; Ljungholm, 2015; Jaksic, 2013; Maley 2014; Tabatabai, 2014; Qureshi, 2013).

\section{Pengertian Performance Management Planning \\ Planning di dalam siklus manajemen kinerja} berarti menetapkan harapan dan sasaran kinerja bagi kelompok dan individu untuk menyalurkan usaha mereka demi mencapai tujuan organisasi. Performance planningini dilakukan oleh manajer dan bawahan secara bersamaan. Karyawan yang terlibat dalam proses perencanaan (planning) akan membantu mereka memahami tujuan organisasi, apa yang perlu dilakukan, mengapa proses perencanaan itu perlu dilakukan, dan 
seberapa baik proses perencanaan itu harus dilakukan (Armstrong, 2006; United States Office of Personnel Management, 2017).

\section{Pengertian Training and Development}

Training and development adalah salah satu bagian dari performance management yang menyediakan perbaikan dan peningkatan proses kerja yang terperinci dan oleh karena itu dampaknya harus dipantau, dikendalikan dan diukur untuk mendapatkan hasil terbaik dalam mengembangkan tenaga kerja yang berpendidikan, serta terampil. Karyawan harus didorong dan dimotivasi tidak hanya dengan gaji, tetapi juga dengan program pelatihan dan pengembangan, kesehatan, sosial dan lainnya, yang akan meningkatkan minat, kepercayaan dan komitmen mereka kepada perusahaan sehingga perusahaan akan mengarah pada keuntungan yang lebih besar (Qureshi, 2013; Jaksic, 2013).

\section{Pengertian Coaching and Mentoring Coaching}

Setelah melakukan sesi training and development, karyawan akan masuk kepada sesi pembinaan atau coaching. Pembinaan atau coaching yaitu proses yang terus-menerus dan kolaboratif dimana manajer berinteraksi dengan karyawannya dan berperan aktif dan tertarik dalam kinerjanya. Biasanya, coaching mencakup pengarahan, memotivasi, dan menghargai perilaku karyawan. Pelatihan adalah fungsi sehari-hari yang melibatkan pengamatan kinerja, memuji pekerjaan yang telah dilakukan dengan baik, dan membantu memperbaiki kinerja yang tidak sesuai harapan atau standar (Aguinis, 2013)

\section{Pengertian Performance Appraisal}

Penilaian kinerja (performance appraisal) dapat didefinisikan sebagai laporan penilaian secara formal untuk setiap individu di dalam organisasi yang dinilai langsung oleh manajer atau atasan langsung mereka, biasanya tinjauan tersebut dilakukansecara tahunan dengan mengadakan pertemuan langsung antar atasan dan bawahan. Konsep performance appraisal pada intinya berfungsi untuk membangun ketrampilan karyawan di masa yang akan datang (Armstrong, 2006).

\section{Pengertian Feedback}

Umpan balik atau feedback berguna untuk memberikan informasi tentang kinerja karyawan serta membantu manajemen dalam memberikan tindakan perbaikan. Di dalam proses umpan 26 balik di beberapa perusahaan biasanya memiliki sistem untuk menangani feedback, yang dimana sistem tersebut menyediakan informasi untuk dipresentasikan kepada orang-orang mengenai kinerjanya, sistem feedback tersebut membantu mereka untuk memahami seberapa baik kinerjanya dan seberapa efektif perilaku mereka. Tujuan umpan balik atau feedback tersebut antara lain untuk memberikan tindakan yang tepat yang dapat perusahaan lakukan. Ini bisa menjadi tindakan positif untuk memanfaatkan peluang yang telah ditunjukkan oleh sistem feedback tersebutyaitu berupa tindakan yang bersifat korektif di mana feedback tersebut telah mengungkapkan bahwa ada sesuatu yang tidak beres pada kinerja karyawan (Armstrong, 2006).

\section{Hambatan Penerapan Performance Management}

Adapun beberapa hambatan yang ditemukan di beberapa negara mengenai masalah dari performance management akan dikemukakan oleh peneliti melalui tabel 2 .

Melihat tabel permasalahan performance management tersebut maka peneliti ingin membuat sebuah rancangan sistemyang akan berfungsi untuk meningkatkan kinerja perusahaan. Cara meningkatkan kinerja perusahaan yaitu dengan berbagai cara seperti memberikan job description yang detail kepada karyawan, yaitu mencakup penjabaran wewenang dan tanggung jawab, kondisi pekerjaan, fasilitas kerja, dan standar hasil kerja (Pattisahusiwa, 2013). Karyawan juga harus ditunjang dengan jenjang karir yang jelas, di dalamnya mencakup kenaikan gaji, promosi, demosi, hingga pemindahtugasan (Farheen Mughal, 2014). Karyawan juga memerlukan adanya coaching and mentoring, pelatihan dan pengembangan, penilaian kinerja yang obyektif, pemberian feedback, hingga pemberian reward ataupun punishment yang jelas. Rangkaian proses dan tindakan tersebut merupakan sistem performance management (Mughal, 2014; Qureshi, 2013). Performance managementakan memberikan dampak karyawan lebih berkomitmen terhadap organisasi (Bhosale, 2015). Adapun hasil dari karyawan yang memiliki komitmen tinggi terhadap organisasi akan memberikan keuntungan bagi perusahaandiantaranyadapat meningkatkan kinerja serta daya saing organisasi. Peningkatan kinerja serta daya saing organisasi dapat dilihat dari meningkatnya kualitas produk yang dihasilkan oleh perusahaan. Dengan 
meningkatnya kualitas produk maka akan membawa perusahaan tersebut unggul di dalam persaingan yang dimana akan berdampak padapeningkatanprofit perusahaan (Wahyudi, 2012).

Tabel 2. Masalah Performance Management di Beberapa Negara

\begin{tabular}{|c|c|c|c|c|}
\hline No. & Negara & $\begin{array}{c}\text { Masalah Performance } \\
\text { Management }\end{array}$ & Dampak & Solusi \\
\hline 1 & $\begin{array}{l}\text { Botswana, } \\
\text { South } \\
\text { Africa }\end{array}$ & $\begin{array}{l}\text { - Buruknya desain dan } \\
\text { implementasi dari Sistem } \\
\text { Performance Management yang } \\
\text { dilakukan oleh pemerintah } \\
\text { Botswana terhadap komite } \\
\text { pengembangan staf pada } 13 \\
\text { sekolah menengah pertama di } \\
\text { Gaborone } \\
\text { - Tidak terdapat feedback atau } \\
\text { komunikasi yang beik antar } \\
\text { penanggung jawab sistem atau } \\
\text { atasan langsung terhadap } \\
\text { bawahan } \\
\text { - Tidak terdapat Motivasi yang } \\
\text { baik terhadap bawahan } \\
\text { - Penilaian yang bias yang } \\
\text { mengakibatkan tidak efektiffrya } \\
\text { perfornance management } \\
\text { system tersebut }\end{array}$ & $\begin{array}{l}\text { Penurunan Motivasi } \\
\text { Karyawan atau } \\
\text { bawahan }\end{array}$ & $\begin{array}{l}\text { - Strategi komunikasi dan } \\
\text { umpan balik dari } \\
\text { performance management } \\
\text { system harus dikembangkan } \\
\text { - Sistem reward pada } \\
\text { performance management } \\
\text { system tersebut harus } \\
\text { dilaksanakan sepenuhnya } \\
\text { sebagai strategi motivasi } \\
\text { - Praktik dari performance } \\
\text { management system yang } \\
\text { telah berhasil harus } \\
\text { didokumentasikan untuk } \\
\text { dijadikan referensi. } \\
\text { - Untuk mengurangi bias } \\
\text { penilaian, para guru staf } \\
\text { kantor regional harus } \\
\text { melakukan kunjungan } \\
\text { pemantauan rutin ke } \\
\text { sekolah untuk mernverifikasi } \\
\text { skor PMS yang dikirimkan } \\
\text { kepada mereka terhadap } \\
\text { dokumen pendukungnya. } \\
\text { - Penilaian PMS harus } \\
\text { sesuai standar di seluruh } \\
\text { penilai dan sekolah, } \\
\text { sehingea pelatihan } \\
\text { supervisor mengenai } \\
\text { penilaian dan penjaminan } \\
\text { mutu harus ditingkatkan } \\
\text { (Macheng Boipono, 2014) }\end{array}$ \\
\hline 2 & $\begin{array}{l}\text { Uganda, } \\
\text { East Africa }\end{array}$ & $\begin{array}{l}\text { - Terdapat celah di dalam } \\
\text { implementasi manajemen } \\
\text { kinerja (performance } \\
\text { management) pada sektor } \\
\text { kesehatan di Uganda } \\
\text { - Ada kekurangan dalam } \\
\text { menetapkan target kinerja } \\
\text { - Perencanaan manajemen } \\
\text { kinerja hampir tidak dilakukan. }\end{array}$ & $\begin{array}{l}\text { - Prospek yang } \\
\text { terbatas untuk } \\
\text { kemajuan karir } \\
\text { - umpan balik } \\
\text { kinerja yang tidak } \\
\text { memadai } \\
\text { •mekanisme } \\
\text { penghargaan yang } \\
\text { buruk }\end{array}$ & $\begin{array}{l}\text { - Komunikasi dan umpan } \\
\text { balik yang efektif } \\
\text { - Motivasi } \\
\text { - Strategi penilaian yang } \\
\text { jelas. } \\
\text { (George William Lutwama, } \\
\text { 2013) }\end{array}$ \\
\hline 3 & Indonesia & $\begin{array}{l}\text { - Tidak objektifnya pejabat atau } \\
\text { atasan PT. Petrokimia Gresik di } \\
\text { dalam memberikan Penilaian } \\
\text { Akhir Kinerja (PAK) }\end{array}$ & $\begin{array}{l}\text { - Tim pengelola } \\
\text { sistem manajemen } \\
\text { kinerja sulit } \\
\text { mengidentifikasi } \\
\text { karyawan yang } \\
\text { memiliki kompetensi } \\
\text { unggul dan } \\
\text { karyawan yang } \\
\text { memiliki kompetensi } \\
\text { biasa saja. }\end{array}$ & $\begin{array}{l}\text { - Perlunya kesodaran, } \\
\text { kedisiplinan, dan } \\
\text { keterlibatan dalam setiap } \\
\text { prosesnya. } \\
\text { - Para karyawan hendaknya } \\
\text { lebih terbuka dan jujur } \\
\text { tentang apa yang } \\
\text { memotivasi mereka, apa } \\
\text { yang mereka suka dan tidak } \\
\text { suka, tentang yang mereka } \\
\text { lakukan, apa yang mereka } \\
\text { inginkan, apa yang menjadi } \\
\text { kepentingan merekan dan } \\
\text { bagaimana harapan mereka. } \\
\text { - Manajer harus jujur } \\
\text { menyatakan kebenaran } \\
\text { dalam hubungannya dengan } \\
\text { bawahan tentang apa yang } \\
\text { disuka dan tidak disuka, } \\
\text { tentang apa yang mereka } \\
\text { kerjakan, apa apresiasinya } \\
\text { terhadap pekerja, visi yang } \\
\text { diberikan kepada mereka, } \\
\text { persepsi dan penilaian yang } \\
\text { objektif (Ismania Hidayati, } \\
\text { 2014) }\end{array}$ \\
\hline 4 & $\begin{array}{l}\text { United } \\
\text { Kingdom }\end{array}$ & $\begin{array}{l}\text { - Usaha untuk mengembangkan } \\
\text { dan menguji seperangkat KPI } \\
\text { untuk keselamatan dan } \\
\text { keamanan bandara yang } \\
\text { terkendala sulitnya mengukur } \\
\text { kinerja dari peran FM (Facility } \\
\text { Management) di Airport }\end{array}$ & $\begin{array}{l}\text { - Adanya resiko } \\
\text { keamanan bandara } \\
\text { berupa tindak } \\
\text { kejahatan dan } \\
\text { terorisme }\end{array}$ & $\begin{array}{l}\text { - Adanya perbaikan yang } \\
\text { jelas dalam sistem penilaian } \\
\text { secara berkesinambungan } \\
\text { dengan cara melakukan } \\
\text { Performance } \\
\text { Measurement, } \\
\text { benchmarking. } \\
\text { mengidentifiaksi KPI, target, } \\
\text { serta kinerja dengan jelas } \\
\text { dan benar. } \\
\text { (Aghahowa Enoma, 2007) }\end{array}$ \\
\hline
\end{tabular}

\section{METODE PENELITIAN}

Metode penelitian menggunakan pendekatan analisis kualitatif. Analisis kualitatif adalah analisis di mana peneliti menggunakan pendekatan model performance management model.

\section{Performance Management Model}

Dari pemikiran beberapa teori dan berdasarkan penelitian-penelitian terdahulu tentang praktik performance management di berbagai negara,maka peneliti dapat menarik sebuah model performance management sebagai berikut:

Gambar 2. Rancangan Model Performance Management

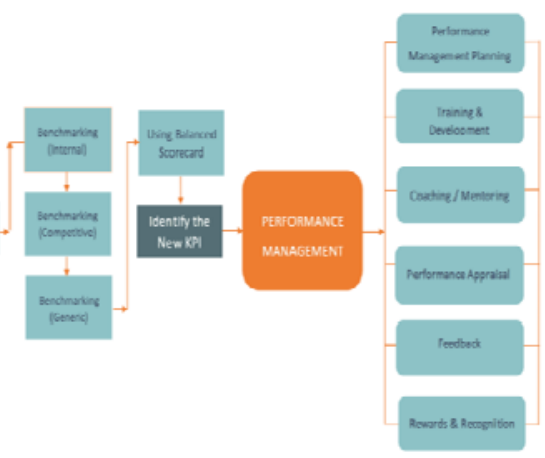

Sumber: Bhatti 2013; Sarel Lavy, 2010; Ljungholm, 2015; Maley, 2014; Tabatabai, 2014; Waal, 2007; Moeheriono, 2009; Ingram, 1996; Watson, 1996; Jabeen, 2017; Kaplan, 2010; Smither 2009; Jaksic, 2013; Qureshi, 2013; Mughal, 2014; Lutwama, 2013.

Rancangan model performance management yang disajikan pada gambar 2, akan peneliti jelaskandengan urutan proses sebagai berikut :

1. Langkah pertama peneliti akan melakukan pengukuran kinerja (performance measurement) sebelum membentuk suatu sistem manajemen kinerja. Adapun pengukuran kinerja tersebut digunakan untuk mengevaluasi dan mengendalikan keseluruhan operasi bisnis. Performance measurement berguna untuk mengukur dan membandingkan kinerja berbagai organisasi di industri, pabrik, departemen, tim dan individu. Pengukuran kinera melalui pembentukan KPI akan membantu tim manajemen senior untuk membuat keputusan strategis yang penting. Dengan demikian, awal pengukuran kinerja dimulai dari 
identifikasi indikator kinerja yang memungkinkan spesifikasi pada proses kinerja yang terperinci (Bhatti, 2013; Lavy, 2010)

2. Performance measurement yang efektif dapat diukur melalui KPI (Key Performance Indicators) (Jabeen, 2017; Ljungholm, 2015; Maley, 2014; Tabatabai, 2014; Waal, 2007). Pada model tersebut, di langkah kedua peneliti akan menganalisa KPI perusahaan untuk mengidentifikasi apakah indikatorindikator kinerja perusahaan tersebut telah sesuai dengan spesifikasi pada proses kinerja yang terperinci (Bhatti, 2013; Lavy, 2010).

3. Langkah ketiga pada model penelitian ini ialah melakukan strategi benchmarking yaitu mengukur tingkat capaian dan sasaran organisasi, menganalisis hasil pengukuran kinerja kemudian diimplementasikan dengan membandingkan tingkat capaian tujuan dan sasaran organisasi tersebut (Moeheriono, 2009). Benchmarking dapat dilakukan dengan cara menerapkan kerangka kerja dan indikator-indikator yang sesuai untuk mengukur kinerja, kemudian setelah indikator kinerja tersebut ditetapkan, maka organisasi harus membandingkan kinerja tersebut dengan kinerja bisnis sejenis lainnya (Ljungholm, 2015; Ingram, 1996). Ada 3 tahapan benchmarking yaitu benchmarking internal, kompetitif serta generik. Pada langkah ketiga peneliti akan menggunakan strategi benchmarking internal terlebih dahulu yaitu dengan membandingkan antara aktivitas berdasarkan KPI yang telah dianalisis kemudian dilakukan perbandingan di dalam proses internal organisasi. Pendekatan ini bisa dilakukan dengan membandingkan operasi pada suatu bagian atau divisi dengan divisi internal lainnya dalam suatu organisasi (Ljungholm, 2015; Ingram, 1996; Watson, 1996).

4. Langkah keempat yaitu dengan melakukan benchmarking competitive. Benchmarking kompetitif yaitu perusahaan harus membandingkan operasinya dengan para pesaing pada industri yang terkait. Caranya dengan menganalisis indikator-indikator kinerja perusahaan kemudian membandingkannya dengan perusahaan pesaing yang sejenis dengan mengidentifikasi kekuatan dan kelemahan perusahaan pesaing (Ljungholm, 2015; Watson, 1996).
5. Kemudian langkah kelima yaitu dengan menggunakan benchmarking generik, generic benchmarking melihat kearah yang lebih luas, yaitu dengan membandingkan proses bisnis atau fungsi bisnis dalam rangka untuk mengidentifikasi praktek perusahaan terbaik pada industri yang tidak berkaitan. Caranya dengan menganalisis indikatorindikator kinerja perusahaan kemudian membandingkannya dengan perusahaan terbaik yang tidak sejenis (Ingram, 1996; Ljungholm, 2015).

6. Setelah melakukan benchmarking maka akan didapat suatu indikator-indikator kinerja yangnantinya akan dibentuk menjadi KPI yang baru. Berdasarkan beberapa teori yang telah peneliti rangkum, bahwa KPI tersebut belum bisa digunakan karena masih melihat dari sisi non-financial, sedangkan perusahaan membutuhkan suatu alat untuk meneliti aspek keuangannya. Melihat dan menganalisa aspek keuangan perusahaan berfungsi untuk memperbaiki kinerja keuangan secara berkesinambungan (Moeheriono, 2009). Performance measurement yang efektif dapat diukur melalui KPI (Key Performance Indicators). Penggunaan instrumen seperti KPI akan lebih obyektif bilamana perusahaan menggunakan teknik balanced scorecard terlebih dahulu. Dengan penggunaan balanced scorecard maka perusahaan akan menjelaskan kinerja dan tujuan organisasi secara jelas (Jabeen, 2017; Ljungholm, 2015; Maley, 2014; Tabatabai, 2014; Waal, 2007). Berdasarkan teori yang telah dikemukakan, maka pada langkah ke enam ini peneliti akan menggunakan metode balanced scorecard untuk mengetahui aspek financial dan nonfinancial tersebut. Metode balanced scorecard yang akan digunakan oleh peneliti adalah metode balanced scorecard yang dikemukakan oleh Robert S. Kaplan. Metode balanced scorecard ini dihitung melalui empat perspektif yang berfungsi untuk mengevaluasi kinerja perusahaan, beberapa jenis perpsektif tersebut antara lain, yaitu: financial perspective, customer perspective, internal business process perspective, dan learning and growth perspective (Kaplan, 2010; Jabeen, 2017)

7. Setelah balanced scorecard dilakukan maka akan membentuk beberapa indikatorindikator baru, yang akan lebih obyektif 
untuk dijadikan sebuah KPI yang baru (Jabeen, 2017; Ljungholm, 2015; Maley, 2014; Tabatabai, 2014; Waal, 2007). Pada langkah ke tujuh ini, KPI yang baru tersebut akan dijadikan acuan untuk pedoman dalam membentuk suatu rancangan manajemen kinerja. Di dalam rancangan manajemen kinerja tersebut antara lain terdapat performance management planning yang mencakup penetapan tujuan dan sasaran, dengan menekankan pada proses tahapan dari model PDCA (Plan, Do, Check Action). Plan, ketika peneliti menetapkan ukuran, target, dan sasaran berdasarkan tindakan yang sesuai serta relevan untuk hal-hal yang ingin kita nilai dan tingkatkan. Do, yaitu mengambil tindakan yang terkait dengan tujuan atau target yang telahdirencanakan dan ditetapkan pada langkah sebelumnya. Check, yang berarti peneliti akan memantau dan mengevaluasi proses serta hasil terhadap sasaran dan target yang telah direncanakan kemudian melaporkan hasilnya. Action, menindaklanjuti hasil untuk membuat perbaikan yang diperlukan jika terdapat perbedaan antara hasil, target serta sasaran yang akan dicapai dengan realisasinya. Hal ini berarti juga meninjau seluruh langkah dan memodifikasi prosesnya untuk memperbaiki beberapa indikator-indikator yang terdapat pada KPI.Dengan penerapan prosedur yang digambarkan sebagai model PDCA, hubungan antara yang terealisasi dan yang direncanakan akan bisa ditetapkan (Jaksic, 2013). Kemudian pada manajemen kinerja di dalamnya juga mencakup pembinaan dan pengembangan staf, penilaian kinerja, feedback, evaluasi kinerja secara formal serta menghubungkan kinerja dengan penghargaan, sehingga tujuan dari proses yang berlangsung tersebut dapat meningkatkan kinerja karyawan (Smither 2009; Ljungholm, 2015; Jaksic, 2013; Maley 2014; Tabatabai 2014; Qureshi, 2013).

\section{Kesimpulan dan Saran}

Perusahaan harus mengupayakan cara untuk memaksimalkan performance managemenet (PM) yaitu dengan cara mengukur kinerja perusahaan terlebih dahulu dengan mengidentifikasi KPI perusahaan. Strategi benchmarking dapat dilakukan perusahaan membandingkan produk, layanan dan proses kerja mereka dengan organisasi lain untuk meningkatkan kualitas. Produk, layanan, dan proses kerja tersebut dapat berguna untuk memberikan masukan bagi KPI yang baru. Penggunaan aspek-aspek seperti KPI, serta benchmarking dirasa belum cukup, karena aspekaspek tersebut hanya melihat dari perspektif non keuangan, sedangkan saat ini manajemen dituntut untuk meningkatkan kemampuan perusahaannya dalam melipatgandakan kinerja keuangan secara berkesinambungan. Maka dari itu metode balanced scorecard digunakan untuk menjawab permasalahan tersebut. Metode balanced scorecard dapat mengidentifikasi indikator-indikator yang baru yang nantinya akan menjadi pedoman penilaian bagi eksekutif untuk menilai bawahannya. Indikator-indikator tersebut bilamana dirangkai akan menjadi kunci atau alat untuk mengukur tingkat keberhasilan seseorang dalam menjalankan dan melaksanakan tugasnya. Serangkaian indikator kinerja tersebut lebih dikenal dengan nama Key Performance Indicators. Sebuah KPI yang baru berguna sebagai pedoman untuk menyusun penilaian kinerja yang nantinya akan menjadi fondasi dari keseluruhan proses performance management di dalam organisasi.Manajemen kinerja mengacu pada proses yang berkelanjutan yang mencakup penetapan dan perencanaan tujuan serta sasaran, pembinaan dan pengembangan staf, penilaian kinerja, feedback, serta menghubungkan kinerja dengan penghargaan, sehingga tujuan dari proses yang berlangsung tersebutdapat meningkatkan kinerja karyawan sehingga akan berdampak pada peningkatan profit perusahaan.

\section{REFERENSI}

Aguinis, H. (2013). Performance Management (3rd ed.). Boston, United States of America: Prentice Hall

Asropi, S. M. (2007). Membangun Key Performance Indicator Lembaga Pelayanan Publik . Manajemen Pembangunan, 57

Armstrong, M. (2006). Performance Management Key Strategies And Practical Guidelines (Third Ed.). London, United Kingdom: Kogan Page Limited

Bhatti, M. I. (2013). The key performance indicators (KPIs) and their impact on overall organizational performance. Quality and Quantity

Bhosale, U. (2015). Performance Management System And Organizational Commitment. International Journal of Organizational Behaviour \& 
Management Perspectives, 4 No.2, 1728-1731

Boipono, M. (2014). Implementation of Performance Management System (PMS) In Schools : Success Factors. Natural and Social Sciences , 2(5), 189194

Carlucci, D. (2010). Evaluating and selecting key performance indicators: an ANP-based model. Measuring Business Excellence, Vol.14, No. 2, 66-76

Enoma, A. (2007). Developing key performance indicators for airport safety and security. Vol. 25, No. 7

Ingram, H. (1996). Linking teamwork with performance. Team Performance Management: An International Journal, Vol. 2 No.4(4), 5-10

Hidayati, I. (2014). Analisis Penerapan Sistem Manajemen Kinerja Berbasis Kompetensi (Studi Pada PT Petrokimia Gresik). Jurnal Administrasi Bisnis (JAB), Vol. 15 No. 1

Jabeen, F. (2017). Exploring the status and effects of balanced scorecard adoption in the non-western context Evidence from the Middle East. Journal of Management Development, Vol. 36, No. 8, 1063-1075

Jaksic, M. (2013). Performance Management And Employee Satisfaction. Montenegrin Journal Of Economics, Vol 09 (01), 85-92.

Kaplan, R. S. (2010). Conceptual Foundations of the Balanced Scorecard (Vol. 3). Boston, USA: Harvard Business School

Lavy, S. (2010). Establishment of KPIs for facility performance measurement: review of literature. Facilities, 28 No. 9/10, 440-464

Ljungholm, D. P. (2015). The Practice Of Performance Management In Public Sector Organizations. Geopolitics, History, and International Relations, 7(2), 2015, ISSN 1948-9145, 190-196

Lutwama, G. W. (2013). Assessing the implementation of performance management of health care workers in Uganda. BMC Health Services Research, 1472-6963/13/355

Maley, J. (2014). Sustainability: the missing element in performance management. Asia-Pacific Journal of Business Administration, 6(3), 190-205

Moeheriono. (2009). Pengukuran Kinerja Berbasis Kompetensi (1 ed., Vol. 1). (R.
F. Sikumbang, Ed.) Bogor, Jawa Barat, Indonesia: Ghalia Indonesia.

Mughal, F. A. (2014). Implementation and Effectiveness of Performance Management System in Alfalah Bank. (S. S. Ali, Ed.) Journal of Public Administration and Governance,Vol. 4, No.4

Pattisahusiwa, S. (2013). Pengaruh Job Description Dan Job Specification Terhadap Kinerja Proses . Jurnal Akuntabel, Vol.10 No. 1

Qureshi, A. (2013). Impact of performance management on the organisational performance: An analytical investigation of the business model of McDonalds. International Journal of Academic Research in Economics and Management Sciences, 2(5)

Rohaga, T. T. (2014). Jurnal Administrasi Bisnis. (G. Pawitan, Ed.) Jurnal Ilmiah Ilmu Administrasi Bisnis, 10(2), 99-200

Smither, J. W. (2009). Performance Management Putting Research into Action. (M. L. James W. Smither, Ed.) San Francisco, USA: Society for Industrial and Organizational Psychology

Tabatabai, S. A. (2014). A Conceptual Model For Performance Management In Organizations . Arabian Journal of Business And Management Review, 3, No.10(A)

United States Office of Personnel Management. (2017). A Handbook for Measuring Employee Performance. Washington, USA: OPM.GOV

Waal, A. D. (2007). Successful performance management? Apply the strategic performance management development cycle! Measuring Business Excellence, 11 No. 2, 4-11

Waal, A. D. (2011). The impact of performance management on the results of a nonprofit organization. International Journal of Productivity and Performance Management, 60 No. 8, 2011, 778-796

Wahyudi, A. (2012). Membangun Komitmen Organisasional Untuk Meningkatkan Kinerja Dan Daya Saing Organisasi.

Watson, G. H. (1996). Strategic Benchmarking. Jakarta, Indonesia: PT. Gramedia Pustaka Utama. 